\title{
Miranda
}

Revue pluridisciplinaire du monde anglophone /

Multidisciplinary peer-reviewed journal on the English-

speaking world

5 | 2011

South and Race / Staging Mobility in the United States

\section{The Constant Traveller: Staging Mobility in the Poetry of Robert Frost}

\section{Candice Lemaire}

URL: http://journals.openedition.org/miranda/2441

DOI: $10.4000 /$ miranda. 2441

ISSN: 2108-6559

Publisher

Université Toulouse - Jean Jaurès

\section{Electronic reference}

Candice Lemaire, "The Constant Traveller: Staging Mobility in the Poetry of Robert Frost", Miranda

[Online], 5 | 2011, Online since 29 November 2011, connection on 16 February 2021. URL: http:// journals.openedition.org/miranda/2441 ; DOI: https://doi.org/10.4000/miranda.2441

This text was automatically generated on 16 February 2021.

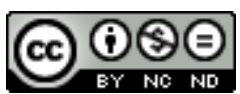

Miranda is licensed under a Creative Commons Attribution-NonCommercial-NoDerivatives 4.0 International License. 


\title{
The Constant Traveller: Staging Mobility in the Poetry of Robert Frost
}

\author{
Candice Lemaire
}

1 I was thinking of the extravagance of the universe, [...] what an extravagant universe it is. And the most extravagant thing in it, as far as we know, is man [...]. And poetry is a sort of extravagance, in many ways. It's something that people wonder about. (Poirier 902)

2 As American poet Robert Frost explains to the students of Dartmouth College in November 1962 (in an address entitled On Extravagance: A Talk), his poetical art is placed under the guidance of the concept of extravagance. More than a mere expression of American extravagance (understood as "eccentricity", "excess", or "spectacular flamboyance"), Frost's poetry can be seen as a product of an extreme "extra-vagance", understood as a poetry of wandering rather than of wondering. Frost's poetical "extravagance" is his constant wandering beyond his bounds, within and beyond the geographical limits of his territory (as the Latin etymology of "extravagance" justifies: extra-vagari, to wander outside, to exceed the bounds of a space). ${ }^{1}$ Robert Frost-"extravagant" artist and traveller-poet-turns his poetry collections into the geographical stage of his constant mobility over the American space and abroad, framing and illustrating his eastbound journey as a wanderer, a speaker, a walker and a farmer, on the open stage of the United States as well as within his own secret theater of New England.

\section{1. "Going for water": the conq(W)est of the East}

3 Robert Frost's poetical work is the faithful reflection of his constant geographical and mental displacement-a wandering between the enclosed and the open, between the thrill of the limitless gradually made home and the warm cosiness of the limited, as Frost himself would emphasize: "I never tire of being shown how the limited can make 
snug in the limitless" (Poirier, 738). This comfort of the vast and the speakers' slow appropriation of the geographical unknown in the collections are accounted for by the poet's fascination for the figure of the cast-away and the wanderer: when asked what his favorite books were, Frost ranked, as written in 1936 to the Massachusetts Library Association, The Odyssey, Robinson Crusoe and Thoreau's Walden in his top-three.

Robinson Crusoe is never quite out of my mind. [...] Walden has something of the same fascination. Crusoe was cast-away; Thoreau was self-cast away. Both found themselves sufficient. (Poirier 738)

4 Frost shared with his New England predecessor Thoreau this liking for sporadic disappearances from the social sphere and the human world, in an intentional retreat to some protective margins-his cabin in Vermont, his farms in New Hampshire, or his winter houses in southern Florida's Key West and Miami. Casting himself away into the society of trees was the poet's saving "step backward taken," or rather his step eastward taken since Frost's poetical mobility over the first part of his life was an eastbound movement, from the West Coast to the East Coast of America and beyond, further East, to England (in 1912). Literary icon of his country, Frost pushed back his poetical Frontier from the Californian suburbs of San Francisco to the waves of the Massachusetts coast, in the opposite direction his nation's history had taken, embracing his homeland's vastness in one stride as "A Record Stride" narrates:

In a Vermont bedroom closet

With a door of two broad boards

And for back wall a crumbling old chimney

(And that's what their toes are towards)

I have a pair of shoes standing

Old rivals of sagging leather

Who once kept surpassing each other

But now live even together.

They listen for me in the bedroom

To ask me a thing or two

About who is too old to go walking

With too much stress on the who.

I wet one last year at Montauk

For a hat I had to save.

The other I wet at the Cliff House

In an extra-vagant wave.

Two entirely different grandchildren

Got me into my double adventure.

But when they grow up and can read this

I hope they won't take it for censure.

I touch my tongue to the shoes now

And unless my sense is at fault

On one I can taste Atlantic

On the other Pacific, salt.

One foot in each great ocean

Is a record stride or stretch.

The authentic shoes it was made in

I should sell for what they would fetch.

But instead I proudly devote them

To my museum and muse;

So the thick-skins needn't act thin-skinned

About being past-active shoes.

And I ask all to try to forgive me

For being as over-elated 
As if I had measured the country

And got the United States stated. (Poirier 267-8)

The two shoes are the "extra-vagant" subjects of this poem, written after a short comeback visit to San Francisco in 1931: Jeffrey S. Cramer notes that Frost hyphenated the word "extra-vagant" in the fourth stanza to either act on the metrical length of the line or to allude to Thoreau who also hyphenated the word in Walden, reinforcing once more the feature of "extra-vagance" they share. ${ }^{2}$ From the Cliff House restaurant on the Pacific shoreline in San Francisco (where Frost used to go when he was a little boy) to the Vermont chimney, the pair of shoes-a physical fragrance of leather and salt, the taste of American vastness finally bridged-stands as the gustative (Marcel Proust-like) remembrance of the speaker's West to East crossing of the territory. While tonguetasting their itinerary, the shoes are also tongued and made to speak to their journeys. Punning on the plurality of the word "record", the shoes are both recording, i.e. sensorily recalling the instant of a metaphorical junction between two sides of the same continent, and breaking the record of distance in striding over the American land, making of such a geographical feat a record stride for the speaker and a record stretch for America. The giant strides of the shoes combine the two coasts into one nation, as the constant pun on the pair "one/two" illustrates: "once, one" versus "two boards, too old, too much, into", blending into "a pair, double, one and the other". The ambivalent Frostian foot is therefore the physical emblem of a geographical journey across the American space and the metrical means of a poetical journey "across spaces of the footed line[s]" in the poems.

As Frost's biographer Jay Parini wrote:

Because Frost is so intimately associated with rural New England, one tends to forget that the first landscape printed in his imagination was both urban and Californian. That he came to appreciate, and to see in the imaginative way a poet must see, the imagery of Vermont and New Hampshire has something to do with the anomaly of coming late to it. 'It's as though he were dropped into the countryside north of Boston from outer space, and remained perpetually stunned by what he saw', Robert Penn Warren observed. [...]'A native takes, or may take, a place for granted; if you have to earn your citizenship, your locality, it requires a special focus'. (Parini 3)

7 Geographical mobility gave Frost a special focus, an accurate prism to depict New England, by being born and having spent eleven years on the other coast. Frost's mother and her three children left San Francisco for Lawrence, Massachusetts in 1885, after her husband's death, travelling with the coffin on a train over a long, sad journey east. Though still a very young boy when he reached New England, Robert Frost would later stage his Californian recollections over several of his volumes, remembering San Francisco's beach sand in "A Peck of Gold" (1928), superimposing it onto the then longfinished Gold Rush and the 1870s new boom in silver mining:

Dust always blowing about the town

Except when sea fog laid it down

And I was one of the children told

Some of the blowing dust was gold. [...]

Such was life in the Golden State:

Gold dusted all we drank and ate

And I was one of the children told

'We must eat our peck of gold.' (Poirier 228) 

made of sandy mirages and children feeding on stories of past glories. Place of the origins for Frost, frame of his boyhood memories "once by the Pacific", first Californian (aquatic) garden before his poetry recreates it in New England, the Pacific coastline is evoked as the starting-point of his American eastbound journey, the wings to his New England poetical theater.

9 "Going for water" (as mentioned in the eponymous poem from A Boy's Will) from one coast to the other, moving from the Golden to the Green Mountain State of mind, Robert Frost-both "New England stranger" and "chosen Poet Laureate of Vermont", ${ }^{3}$ liked to call himself the bard of America, thus reflecting his poetical activity on the American territory-“barding about", spreading his words, playing his part of poetwalker and constant speaker.

\section{The leaf treader: "barding about"}

Robert Frost tended to consider that his life as an artist fell into two distinct parts: writing poems and "barding about", one being the financial consequence of the other. What he meant by "barding about" was travelling the country, giving readings and talks in colleges, teaching, being a poet in residence on American campuses, winning prizes and honorary degrees at home and abroad (four times Pulitzer-prized), and earning a living from the fees paid for these activities. ${ }^{5}$ The climax of such a promotional occupation was reached towards the end of his life, when reading for President John F. Kennedy's inauguration ceremony, in January 1961, turning Frost into the highly-acclaimed public poetical figure of America as which he is still remembered. Sent away on cultural missions arranged by the State Department (to Brazil, Great Britain, Israel, Greece and most importantly to the then Soviet Union during the Cold War), ${ }^{6}$ appearing on covers of literary magazines such as The Atlantic Monthly, The Saturday Review (of Literature), as well as on mega-circulations such as Time and Life, ${ }^{7}$ Frost had become "the first American who could be honestly reckoned a master-poet by world standards" (Shribam vii). Over his career, spanning half a century, each public reading or talk was carefully staged, and Frost always made it a point to remain a speaker more than a reader, "saying poems" ${ }^{8}$ more than merely reading them out: Frost the lecturer was then in reading performance, directly addressing his audience, making them laugh, react and interact, embodying the perfect

[...] performance artist, [with his] constant gestures of the hands, [his] frequent nod of the head, [his] stance, [his] changing facial expressions-a natural presence not soon forgotten. (Shribman $\mathrm{xx}$ )

Besides such body language in public speeches, the ultimate Frostian props on this stage of verbal seduction were his eyes whose color blue was best described by his Florida neighbor and friend, historian Helen Muir:

Attempting to describe the exact shade of blue for Robert Frost's eyes, we went from 'sky blue' to 'electric' until I decided to use 'arresting' blue eyes. I did so on the grounds that Robert Frost would have leaned more in that direction, knowing fully well that the entire idea would have amused him no end. (Muir 173)

Such a concern for his audience's reaction to his attempt at sharing out his reading accounts for Frost's interest in conversational poetry and regional speech patterns. The 
poems of his first volumes aim at describing the lives of ordinary working people in Frost's turn-of-the-century New England-touches of archaic diction and Yankee dialect are regularly used.

It is then not surprising that a very conversational tone is chosen for poems in early collections like North of Boston and New Hampshire, in which most of the poems are long dramatic monologues, based on a constant interaction and interplay between the speaker and the audience (in Frost, an addressee stated as "you"), with one special occasion or experience taking place in the present and leading to a revelation in the speaker. ${ }^{9}$ The poem "A Servant to Servants" (from North of Boston) is a good example of strict dramatic monologue:

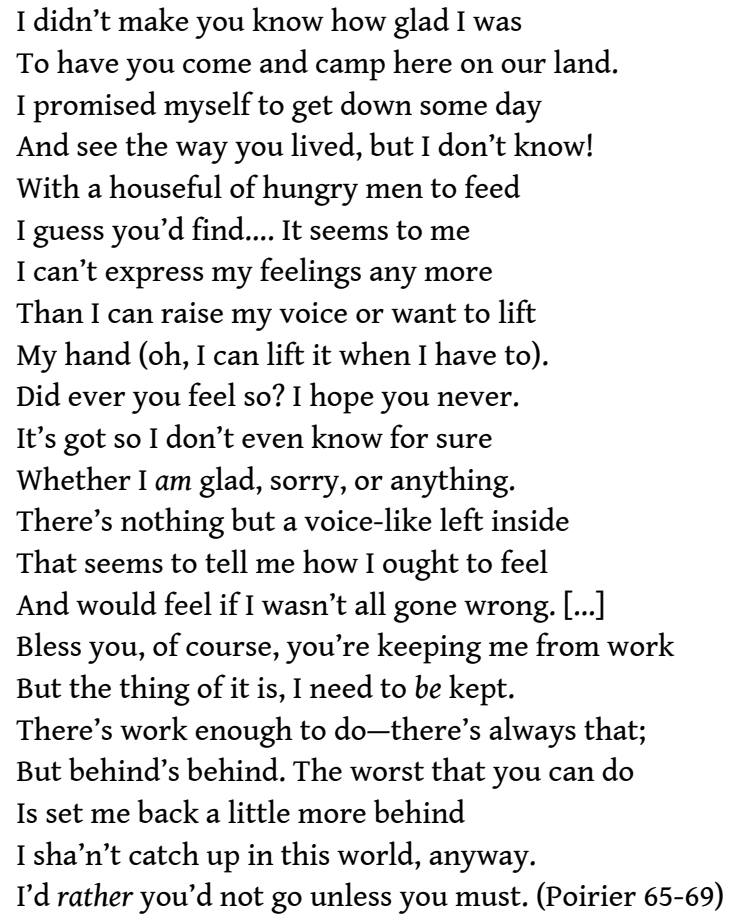

The "voice-like left inside" effect the poem is using is at the core of Frost's dramatic and theatrical tactics, highlighting this apparent conversation between two unnamed voices, one superimposing on the audience of the poem, reader or listener. The "I" of the poem is identified as a woman telling her auditor-friend how glad she is to have her camping on her land. The speaker's self-revelation comes through the projection of her own lifestyle against the background of her friend's way of living ("the way you lived") -she gradually reveals her unhappiness as the wife of a New England farmer who has devoted his life to hard work and frugality. The woman's existence was then only made of heavy house chores, such as cooking for "a household of hungry men". Beside this loss of her sense of pleasure in life, the end of the poem offers her passive nature as the reason for such unhappiness, and the inability to voice her true feelings: "I can't express my feelings anymore". This fake conversation uses the auditor as a mere rhetorical receptacle and an aletheiac device to bring the speaker to her intimate truth. In this poetical staging of a personal epiphany, the theatrical prop used is otherness, this "someone else additional to him" that Frost's poetry is forever seeking. Many of Frost's poems owe a large part of their success to their dramatic nature and draw their energy from the dramatic tension between two or more speakers (for instance "Home Burial" which stages the confrontation between a husband and his wife over their 
baby's death) - two of his dramatic-dialogue poems were indeed adapted and produced for the stage ("The Death of the Hired Man" and "Snow").

But Frost's link with drama is broader than a mere dramatic potential drowned in his verse, since he was also-though not generally known as such-a dramatist and a lifelong lover of the theater. He wrote several plays, notably A Way Out in 1917 (a oneact play depicting an encounter between a hermit and a murderer), The Guardeen ( $\mathrm{a}$ five-scene play about a college student hired as the guardian of a cabin to protect supplies of cider), and In an Art Factory (a one-act conversation play between an artist and his model), both published after his death. His most important plays, however, remain his two masques, A Masque of Reason (in 1945) and A Masque of Mercy (in 1947) which both deal with the human relationship to God. ${ }^{10}$ Frost's early poetry (especially the conversational poetry volumes) can therefore be perceived as performanceoriented, as verse that did not "declare itself in form", as Frost himself stated in his 1929 preface to A Way Out ${ }^{11}$, emphasizing the vital importance of the staying power of poetry due to its dramatic quality: “If it doesn't [have a dramatic accent], it will not stay in anybody's head. It won't be catchy ... Catchiness has a lot to do with it” (Poirier 853).

Though catching his audience's attention was Frost's prime concern when "barding about," he understood his poetry readings as "voyages of discovery" for his auditors, and his volumes do reflect the travelling and walking dimension of his own character. Frost "the leaf-treader", eponymous poem from A Further Range, indeed paved the way for his barding journey thanks to the motif of the shoe in his volumes. As the epitome of Frostian mobility over and outside the American space, the shoe-both a symbol and an object of the poetical "extra-vagance", of the wandering-runs through the collections, connected to the act of treading or even trampling on the ground:

I have been treading on leaves all day until I am autumn-

tired.

God knows all the color and form of leaves I have trodden

on and mired.

Perhaps I have put forth too much strength or been too

fierce from fear.

I have safely trodden underfoot the leaves of another year. (Poirier 270)

The multiplication of the polyptotons "tread/treading/trodden" in the quatrain -a haunting musical transfer of the trampling sound of footsteps on the autumn leafy ground, reinforced by the systematic run-on-lines which cut the staccato effect of the treading-fill up the beginning of the poem with disquieting fricative and dental sounds ("treading/autumn/tired/trodden/put/too/strength/underfoot" and "form/forth/ safely/leaves", and the wind blowing-sounding ternary rhythm "fierce from fear"). Metonymically replaced by the foot in the quatrain, the shoe is the crushing item of the Frostian walk over the lands-the symbolical element of the speaker's escape in the poem "Away!" which Frost quotes in his talk on extravagance:

Now I out walking

The world desert

And my shoe and my stocking

Do me no hurt. (Poirier 426)

Most of the action verbs and the modals have been erased in this telegraphic, jazz-like quatrain, in which the calf of the speaker-metonymically fragmented into shoe and stocking-transitively walks the world and not around the world, embracing in one 
footstep all the numbed and etherised Frostian "desert places"12. The Frostian pair of shoes-the two "extra-vagant" tools of a travelling body-stride over America, from the Golden to the Green Mountain State, as "A Record Stride" (already quoted in part I) reads. The two old leather rivals, forever competing in travelling but statically dwelling in peace in the "Vermont bedroom closet", are only obsessed with knowing which of the twin shoes will first take the road again ("About who is too old to go walking/With too much stress on the who"). Genuine measures of America's continental greatness, the grandchildren-shoes taste of American width, stretching from one salty water border to the other-instruments of a past glory ("past-active shoes") and cradle for America's fifty states ("got the United States stated"), birth of the nation and origin of a walking civilization, a frontier pushed forward from Long Island ("Montauk") to San Francisco, and back (following the Frostian movement of poetical taming of the territory). Friends of the "leaf-treader," the Frostian shoes are also (and above all) means of poetical creation, devoted to the artist's "museum and muse", new writing boards ${ }^{13}$ and enclosed spaces of inspiration. Helen Muir gives us the key to Frost's ritualized use of shoes as props of poetical diversion against stage fright:

The first time [Robert Frost] had attempted to 'say' one of his poems before an audience, he was so overcome he had to turn it over to somebody else. He cured that one night by filling his shoes with pebbles. There was blood in his socks when he finished but it served to cure him, by putting his mind on something else. (Muir 10)

Robert Frost's cathartic pebble-filled shoes ${ }^{14}$ are eventually turned into powerful and dissuasive metrical weapons in the poems, following the notorious-though fascinating for Frost-example of Soviet Premier Nikita Khrushchev who used his shoe as a "parliamentary gavel, [...] taking [it] off and pounding it on the desk before him in an effort to bring [his] assembly to attention", as George Monteiro points out:

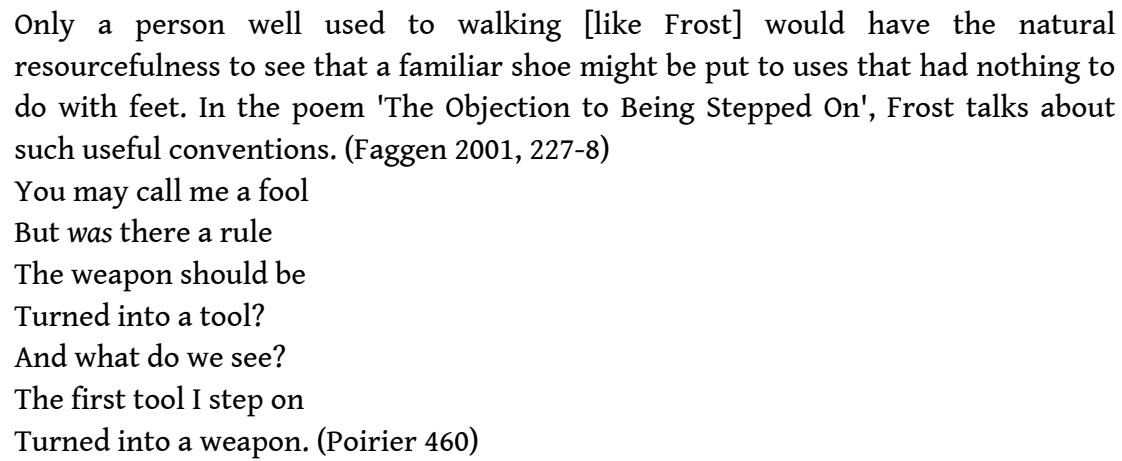

21 Frost's recollection of Khrushchev's politically rhythmical use of his shoe is used here in the final distich of the poem to pace the trimeters, reproducing the triple banging of the shoe within the line, and also sounding the three knocks of the Frostian theater stage.

Theatrical speaker, play-acting bard on the American territory, and giving the beat to his own poetical journey through the leitmotiv of the shoe, Frost's geographical mobility as a national poet is best understood nonetheless through the regional frame of his New England microcosmic theater-his own secret and blurred "North-East of Eden". 


\section{The constant gardener: staging the "North-East of Eden"}

Besides the figure of the constant traveller, Robert Frost also endorses the part of the "constant gardener" of his New England territory: Frost (as a public figure) was appreciative of his own private New England garden for giving him the opportunity to shut his eyes to the world in favor of some personal leisure, such as walking alone through the countryside, planting flowers or raising poultry. Frost's poetical New England garden is very often superimposed onto the Biblical Garden of Eden in the collections, turning the area into a framed vegetation stage located in the "North-East of Eden" as Kenneth Lincoln puts it. ${ }^{15}$ But the Frostian Northeastern Eden is presented as somehow post-lapsarian and the speaker is made the gardener of a cankered nature, as "A Winter Eden" (1928) exemplifies:

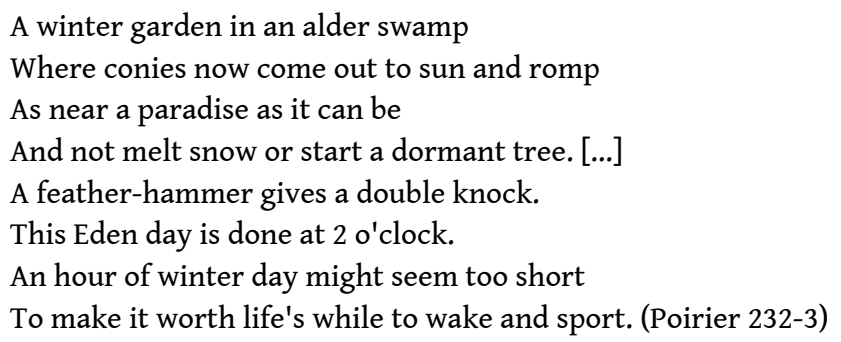

These two quatrains in iambic pentameters offer the closest thing to paradise in the Frostian universe-a somewhat chaotic, swampy garden after the Edenic fall, a snowbound secret and muffled paradise, in which undisturbed sleeping trees are the new playground for loud rabbits. On this earthly paradise cyclical stage in which gravity and weightlessness blend, feathers are turned into hammers to strike the time on heaven bells-only two knocks, lacking a third for the Edenic performance to really take place and add this extra "hour of winter day" to make it "worthwhile to wake and sport".

Frost manages to stage the blurred geography of his "North-East of Eden" through a rhythmical system of name dropping, as in his opening and eponymous poem of the New Hampshire collection, in which the reader is confronted with a random series of American historical landmarks and New England state or city names: "New Hampshire, Dartmouth, Daniel Webster, John Smith, Isles of Shoals, Boston, Harvard College, Salem, Connecticut, Franconia, Massachusetts". ${ }^{16}$ The notion of "North-East of Eden" is also apt to describe Frost's poetical territory insofar as it connects New England to a territory of eternal "extra-vagance": the Biblical East of Eden territory (before becoming a John Steinbeck reference), as stated in the fourth chapter of the Book of Genesis, is called the land of Nod-the place where Cain was exiled to, after killing his brother Abel, located on the east of Eden. "Nod" is the Hebrew root for the verb "to wander", turning Cain into a man cursed to wander the land forever, in an everlasting "extra-vagance". ${ }^{17}$

The Frostian vegetation stage, as embodied by the winter garden, is also doubled by another type of large-scale wild garden, thanks to the motif of the meadow in the volumes, acting almost as a stage direction when used in the first line of the poems: "There were three in the meadow by the brook" (first line of "The Code"), "There's a place called Far-away Meadow" (first line of "The Last Mowing"). Frost the "literate farmer" uses the meadow to direct his personae's lives, and puns on the sound effect of the word to recreate a theatrical meadow-stage in the poems: the noun "meadow" is 
indeed the sounding combination of the noun "mead" (pronounced [mi:d]-also meaning "field, meadow" for poetic licence purposes) and the suffix "-ow"-close correspondence to the wooden "O" of the Elizabethan stage (i.e the round shape of the Globe Theater). The Frostian meadow ("mead-o") can therefore be both understood as the "O-shaped stage in the field" and the "medieval O" of the Elizabethans. ${ }^{18}$ The most common props on this Frostian-O are the flowers mushrooming over the collections: a telephone-flower between the personae in the poem "The Telephone", "dancing flowers", a "flower boat"-all used to guide and gather the personae-actors around them on the vegetal stage of the meadow. The two poems "Flower Gathering" and "Flower Guidance", in which the bee-like persona "went from flower to flower", illustrate this unifying role of flowers ranging from the rose, the iris, to the asphodel and the several species of orchids, framing up the natural setting of the Frostian pastoral stage.

Poetical conqueror of the East and forever outward bound, Robert Frost's work can therefore be better understood through the prism of a constant displacement. From the San Francisco shores, to the Florida sun, the Vermont mountains, to the British thatched houses, and the Russian landscapes, his poetry questions the concept of mobility in its most physical definition. Often "barding about" the stage of the American continent-"saying" poems and wearing off his metrical shoes-this "extravagant" and extravagant artist always came back to his favorite New England flowery stage and audience, down in the meadow of his theatrical "North-East of Eden." In turn actor, performer, cultural ambassador and wanderer on the world's stage until the end of his life, Robert Frost-poet of "not only regional but hemispheric significance"19_ always dreamed of bringing down the fourth wall of his own vegetal stage:

I had withdrawn in forest, and my song

Was swallowed up in leaves that blew always;

And to the forest edge you came one day

(This was my dream) and looked and pondered long

But did not enter, though the wish was strong:

You shook your pensive head as who should say

'I dare not-too far in his footsteps stray-

He must seek me would he undo the wrong.

Not far, but near, I stood and saw it all

Behind low boughs the trees let down outside;

And the sweet pang it cost me not to call

And tell you that I saw does still abide.

But 'tis not true that thus I dwelt aloof

For the wood wakes, and you are here for proof. (Poirier 25)

\section{BIBLIOGRAPHY}

The Bible, Authorized King James Version. Oxford: Oxford World's Classics, 1997.

D'Avanzo, Mario L. A Cloud of Other Poets: Robert Frost and the Romantics. New York: UP of America, 1991. 
Faggen, Robert (ed.). The Cambridge Companion to Robert Frost. Cambridge: Cambridge University Press, 2001.

---. The Cambridge Introduction to Robert Frost. Cambridge: Cambridge University Press, 2008.

Harrap's Chambers Dictionary. London: Chambers Harrap Publishers, 2004.

Hope, Warren. A Student Guide to Robert Frost. London: Greenwich Exchange, 2004.

Lewis Tuten, Nancy and John Zubizarreta (eds.). The Robert Frost Encyclopedia. Westport, CT: Greenwood Press, 2001.

Muir, Helen. Frost in Florida: A Memoir. Miami, FL : Valient, 1995.

Parini, Jay. Robert Frost: A Life. New York: Henry Holt and Co., 1999.

Poirier, Richard and Mark Richardson (eds.). Robert Frost: Collected Poems, Prose and Plays. New York: Library of America, 1995.

Reeve, F.D. Robert Frost in Russia. Zephyr Press, 1970.

Shribman, David M. Introduction. In Robert Frost Speaking on Campus: Excerpts from His Talks (1949-1962). Ed. Edward C. Lathem. New York: W. W. Norton and Co., 2009. i-xxv.

\section{NOTES}

1. The medieval Latin extravagans is the present participle of the verb extra-vagari (to wander beyond/outside, to exceed the bounds of something). Extravagance is therefore the wandering beyond geographical limits, the crossing of borders, the image of a never-ending journey, but also by extension in modern language an excessive, eccentric, unrestrained, unreasonable and wasteful behavior.

For further etymological details, see the Harrap's Chambers Dictionary (409).

2. "I fear chiefly lest my expression may not be extra-vagant enough" (Walden, "Conclusion" - in Henry David Thoreau, Walden: A Fully Annotated Edition, ed. Jeffrey S. Cramer, Yale University Press, 2004), quoted in Lewis Tuten, 301.

3. "Whose horse had pulled him short up on the road/By me a stranger [...]," in the long poem entitled "New Hampshire," opening the New Hampshire collection, and "Breathes there a bard who isn't moved/When he finds his verse understood /And not entirely disapproved /By his country and his neighborhood?", from the poem "On Being Chosen Poet of Vermont," (Poirier 158, 477).

4. Title of a poem from A Further Range collection (Poirier 270-1).

5. Warren Hope gives a precise definition of such "barding about" activity in his Student Guide to Robert Frost (36).

6. Robert Frost was sent as American cultural ambassador to Brazil in August 1954 (with William Faulkner), to Great Britain in 1957, to Israel and Greece in 1961 and to the Soviet Union in August 1962.

7. Frost appeared on the cover of the Saturday Review on the May 30, 1936 and on the April 25, 1942 issues, on the cover of The Atlantic Monthly in February 1964 and November 1966, on Time magazine in October 1950 and on Life in March, 1962.

8. See for instance the end of his Bread Loaf English School Address on June 30, 1955: "I'll say one of the old [poems] Doc Cook asked me to say" (Poirier 829).

9. "A classification of Frost's dramatic monologues can rest on [the following criteria]: speaker, auditor, and the revelation of character. [...] Two poems in Frost's canon-'The Pauper Witch of 
Grafton' and 'A Servants to Servants'-prove to be strict dramatic monologues," as Paola Loreto justifies (Tuten 85).

10. "In A Masque of Reason, Frost dramatizes a confrontation between God, Job and Job's wife Thyatira. [...] A Masque of Mercy focuses more on God's treatment of the individual. Specifically, the masque probes the prophet Jonah's difficulty in reconciling old Testament justice with New Testament mercy" (Tuten 82-84).

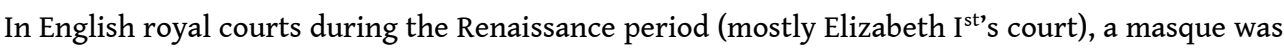
"a dramatic entertainment performed to music by masked actors" (Harrap's Chambers Dictionary, 732).

11. "Everything written is as good as it is dramatic. It need not declare itself in form, but it is drama or nothing" (preface to A Way Out, 1929, in Tuten 84).

12. "Desert Places" is a poem depicting the loneliness of the soul as a downward correspondence to the natural emptiness and void of the world's desert places - interestingly enough, this poem is located right before "The Leaf Treader" in the A Further Range collection.

13. "I never write except with a writing board. I've never had a table in my life. And I use all sorts of things. Write on the sole of my shoe", Robert Frost, 'Paris Review' Interview (with Richard Poirier) (Poirier 873).

14. Frost the orator curing his stage fright using pebbles is an interesting image since it directly brings back to the technique used by another prominent orator, Ancient Athens statesman Demosthenes (384-322 BC). As a boy, Demosthenes had a speech impediment-an inarticulate and stammering pronunciation-which he cured practicing speech with pebbles in his mouth.

15. Lincoln, Kenneth. "Quarrelling Frost, Northeast of Eden". Southwest Review, 2008, 93-111.

16. Dartmouth College is located in Hanover, New Hampshire. Harvard College is in Cambridge, Massachusetts. Salem is a Massachusetts city. Daniel Webster (1782-1852) was an American statesman who rose to regional prominence through his defence of New England shipping interests. Captain John Smith (1580-1631), Admiral of New England, was an English soldier and explorer, remembered for his role in establishing the first permanent English settlement in North America at Jamestown, Virginia. The Isles of Shoals are nine small rocky islands about ten miles southeast of Portsmouth, New Hampshire. Franconia is the location of one of Robert Frost's farms in New Hampshire.

17. Before being taken up by John Steinbeck for his 1952 novel, "East of Eden" is a Biblical phrase referring to the Land of Nod, as Genesis, 4:16 reads: "And Cain went out from the presence of the LORD, and dwelt in the land of Nod, on the east of Eden" (Genesis, 4:16 in The Bible, Authorized King James Version 5).

18. mead /mi:d/ n, poetic or old use: a meadow (Harrap's Chambers Dictionary 737).

19. Letter to Robert Frost written by US assistant Secretary of State Henry F. Holland, dated July 26, 1954, stressing the mission's importance, on Frost's attending the World Congress of Writers in São Paulo, Brazil (Tuten 368).

\section{ABSTRACTS}

Robert Frost's poetical work, analyzed through the prism of a constant displacement and wandering over the American territory and beyond, questions the concept of mobility in its most physical definition-from his Californian birthplace to his chosen homeland, the garden-setting 
of New England he likes to stage in his volumes. Treading and wearing off his (metrical) shoes on the various territories the poems frame (whether they are an Edenic environment or a meadowstage), the Frostian lines voice the silent desire for theatrical performance.

Poésie du déplacement constant, de l'errance sur le territoire américain et au-delà, l'œuvre de Robert Frost interroge le concept de mobilité dans son sens le plus physique, depuis son Ouest natal jusqu'à sa nouvelle terre d'attache : le décor-jardin de Nouvelle-Angleterre, qu'il met en scène dans ses recueils, foulant les territoires du pied, du bout de la chaussure, cherchant à les cadrer sous l'aspect d'Eden ou d'une prairie, dans un désir silencieux de représentation théâtrale.

\section{INDEX}

Keywords: American poetry, mobility, staging, California, New England, travel, extra(-)vagance, shoe, meadow, Eden

Mots-clés: poésie américaine, mobilité, mise en scène, Californie, Nouvelle-Angleterre, voyage, extra(-)vergance, chaussure, prairie, Eden

\section{AUTHORS}

\section{CANDICE LEMAIRE}

ATER

Université Toulouse 2 - Le Mirail

candice.lemaire@laposte.net 